\title{
IMPACTS OF THE WORLD HERITAGE LIST INSCRIPTION: A CASE STUDY OF KAIPING DIAOLOU AND VILLAGES IN CHINA
}

\author{
Wei $\mathrm{HAN}^{1}$, Jianming $\mathrm{CAI}^{2}$, Yigang $\mathrm{WEI}^{3,4,}{ }^{*}$, Ying $\mathrm{ZHANG}^{5}$, Yan $\mathrm{HAN}^{2}$ \\ ${ }^{1}$ Institute of Agricultural Economic and Development, Chinese Academy of Agricultural Sciences, Beijing, China \\ ${ }^{2}$ Institute of Geographic Sciences and Natural Resources Research, Chinese Academy of Sciences, Beijing, China \\ ${ }^{3}$ School of Economics and Management, Beihang University, Beijing, China \\ ${ }^{4}$ Beijing Key Laboratory of Emergency Support Simulation Technologies for City Operation, Beijing, China \\ ${ }^{5}$ School of Management, Minzu University of China, Beijing, China
}

Received 20 February 2019; accepted 16 July 2019

\begin{abstract}
This study aims to investigate the overall impacts of the World Heritage List (WHL) inscription in China from different socioeconomic aspects. Kaiping Diaolou and Villages was chosen as the case study because the long period of preparation for WHL inscription led to residents' deep understanding of its heritage values. Results are as follows. (1) Cultural cognition, sense of belonging, community cohesion and infrastructure were positively improved by the WHL inscription, whereas damage to the community cultural environment slightly increased. (2) In the economic domain, the WHL inscription had generated positive (increase in tourism development and villagers' income and employment and solution to the Diaolou property rights problem) and negative impacts (worse tourism development, unequal income and unsolved property rights problems). (3) The WHL inscription improved the ecological environment and people's attention to environmental protection. Although it also caused environmental damage due to an increase in tourists. (4) The positive impacts on the political domain were reflected by government leadership, community participation and plan and legislation, whereas the negative impacts included limited community participation and insufficient planning. Innovations of this study include constructing a theoretical framework to evaluate the impacts of WHL inscription, analysing the present factors of WHL inscription's impacts and providing development suggestions.
\end{abstract}

Keywords: impacts, World Heritage List, inscription, Kaiping Diaolou and Villages, World Heritage Sites, China.

\section{Introduction}

The establishment of the World Heritage Committee by UNESCO in 1976 led to the simultaneous establishment of the World Heritage List (WHL). Properties inscribed on the WHL possess 'outstanding universal value' (OUV) in terms of culture, history, art and ecology and form a rare and irreplaceable wealth for humankind. By the end of July 2018, 53 properties or locations in China have successfully become World Heritage Sites (WHSs), making China the second country with the most heritage properties in the world following Italy. The commercialisation of heritage to improve economic development and restructuring has become a worldwide property management strategy (Bremner, 2000; Kovács, Wiessner, \& Zischner, 2013; Su, 2015; While, 2006). As a result, real estate companies invest and develop many cultural WHSs, and they gradually become commercialized (Su, 2015; Wei, Lam, Chiang, \&
Leung, 2014; Zhu et al., 2019). Under this condition, the development of WHSs is controlled by the government and real estate companies. However, the attitude of local residents is critical for the sustainable development and management of WHSs, especially those that are residential areas. Kaiping Diaolou and Villages is a typical residential heritage; therefore, it was chosen as a case study.

A successful WHL inscription greatly improves the reputation and attractiveness of a nominated place and nation because of the strong influence of the World Heritage Convention and public recognition to the WHS (Frey, 2013; Timothy, 2011). WHL inscription is an important marketing tool in attracting domestic and international tourists, which is known as the 'tourist-enhancing effect' of WHS (Caust \& Vecco, 2017; Su \& Lin, 2014; Yang, Lin, \& Han, 2010). China's large population creates a huge market for heritage tourism (Yao, Qiu, \& Wei, 2019). This

${ }^{\star}$ Corresponding author. E-mail: weiyg@buaa.edu.cn 
'heritage industry' has become one of the fastest growing service-oriented sectors in the country (Hewison, 1987). For example, after Lang Mountain in Hunan Province was declared as a WHS in 2010, the income from the ticket sales increased from 4 million yuan to 51.3 million yuan in six years, growing by 11.4 times. The increase in the number of tourists results in significant economic benefits for local developments in real estate, transportation and hotel and catering services, among others (Caust \& Vecco, 2017; Y. Chen, Z. Chen, Xu, \& Tian, 2016; Nicholas \& Thapa, 2010). WHSs create economic benefits for local residents in terms of tourism development and enable non-profit functions. The 'branding' (Timothy, 2011) and 'labelling' (Yang et al., 2010) of WHL inscription propagate local cultural cognition and education and the protection and sustainable development of WHSs. These positive outcomes are greatly advocated by the United Nations (Santa-Cruz \& López-Guzmán, 2017). These economic benefits lead to 'WHL inscription fever', especially in China (Wang et al., 2015). The WHL inscription simultaneously generate negative impacts. The large numbers of tourists usually bring problems like traffic congestion, noise and pollution (Caust \& Vecco, 2017; Jones, Yang, \& Yamamoto, 2017; Melanie, 2002). To cater to the preference of tourists, the local culture may become commercialised, which can damage the authenticity and integrity of the heritage properties (Caust \& Vecco, 2017; Kolar \& Zabkar, 2010).

Therefore, the WHL inscription produces positive and negative impacts on local places in different domains. WHL inscription is a focus of research (Adie, 2017; Kim, Wong, \& Cho, 2007; Leask \& Fyall, 2006; Parga Dans \& Alonso González, 2019; Poria, Reichel, \& Cohen, 2013; Timothy, 2011). Many studies explore the effects of WHL inscriptions from the perspective of residents (Noor, Rasoolimanesh, Jaafar, \& Barghi, 2018; Rasoolimanesh, Roldán, Jaafar, \& Ramayah, 2016). These studies focus mostly on the effects of tourism development caused by WHL inscription. However, a WHS not only is a tourist area but also has authenticity and integrity in the fields of culture, art, science and history, particularly for local residents. Therefore, this study explored the complete impacts directly caused by the WHL inscription, not simply by tourism activities.

Exploring the impacts of the WHL inscription on the community and residents' attitudes towards them are critical for the sustainable development and management of WHSs, which are also home to residential communities. Therefore, to explore the impacts of the WHL inscription from residents' perspective, this study has three objectives. Firstly, a theoretical framework for modelling the impacts of the WHL inscription is constructed. Secondly, four major domains of impacts are modelled (social and cultural, economic, environmental and political changes) in Kaiping Diaolou and Villages pre- and post-WHL inscription from the views of local residents, and the detailed reasons and background of these changes and residents' views are explored. Thirdly, the influencing factors of WHL inscrip- tion on Kaiping Diaolou are summarised, and sustainable development strategies for the WHS are recommended. This study sheds light on follow-up studies evaluating the impacts of other WHL inscriptions and provides evidence for comparing different WHL inscriptions.

\section{Theoretical framework}

\subsection{Social and cultural impacts}

The WHL inscription improves community cohesion like a magnet (ICOMOS International Committee on Cultural Tourism, 1999). Local residents cultivate a sense of pride for their hometown and prefer to live in a WHS (Jimura, 2011). In some cases, the WHL inscription acts as a catalyst for local cultural revitalisation and increases local people's understanding of the local culture (Airey \& Shackley, 1998; Evans, 2002). However, the large number of tourists caused by the WHL inscription may cause congestion in the community (Jones et al., 2017; Melanie, 2002). In addition, the local culture of WHSs and their authenticity and integrity may be negatively affected by the commercialisation of culture because of excessive tourism (Caust \& Vecco, 2017; Kolar \& Zabkar, 2010).

\subsection{Economic impacts}

The economic impacts of the WHL inscription are usually correlated with tourism development. The well-known branding of the WHL inscription has a 'greater tourist-enhancing effect' than other destinations (Yang et al., 2010). The UNESCO badge has also been used as a marketing tool to attract more tourists (Caust \& Vecco, 2017). These effects have been demonstrated at the global level ( $\mathrm{Su} \&$ Lin, 2014). Tourism is a useful tool for economic development as it improves related industries (e.g. transportation, real estate, accommodation and catering) and increases employment and income of local residents (Andereck \& Vogt, 2000). Sometimes, local residents can even make a living through tourism. To develop tourism services, infrastructure (e.g. roads, shops, bars, restaurants and hotels, among others) must be constructed quickly (Han, Zhang, Cai, \& Ma, 2019; Naudé \& Saayman, 2005; Wei, Huang, Li, \& Xie, 2016; Zhu, Peng, Wang, \& Fan, 2018). Compared with the economic benefits of tourism, the costs of tourism mainly concentrate on the damage to culture and the environment caused by large tourist flow (Caust \& Vecco, 2017; Yang et al., 2010).

\subsection{Environmental impacts}

The WHL inscription urges local residents to behave in an environmentally friendly manner (Wang et al., 2015; Wei, Z. Wang, H. Wang, Yao, \& Li, 2018; Yu, 2014). The management plan of a heritage site is useful for environmental protection (Wang \& Bramwell, 2012). The negative environmental impacts of the WHS focus on tourism. On the one hand, when the number of visitors is excessive, service facilities are insufficient for the tourists, exceed- 
ing the environmental bearing capacity of the WHS (Wei, Cui, Lam, \& Yuan, 2015; Yang et al., 2010; Wu, Wei, Lam, $\mathrm{Liu}, \& \mathrm{Li}, 2019)$. This effect is contrary to the sustainable requirement of the World Heritage Convention. On the other hand, tourism will damage the environment through visitor littering, artificial landscape and natural resource overuse (Caust \& Vecco, 2017; Wei, Cui, Lam, \& Yuan, 2015; Wei, Huang, Lam, Sha, \& Feng, 2015).

\subsection{Governance of the WHL inscription}

To inscribe properties on the WHL, the government should submit a detailed Protection and Management Plan to the World Heritage Committee (Shackley, 1998). After a successful WHL inscription, the Protection and Management Plan of the heritage should be regularly revised (Bianchi, 2002). The strategy of WHSs should attempt to achieve a balance between protection and tourism development (Wager, 1995). UNESCO encourages the participation of local residents in the protection and development of WHSs (UNESCO World Heritage Centre, 2017). The inscription calls for the engagement of different stakeholders (Jones et al., 2017; Zhang, Guo, Mu, \& Liu, 2016).

In accordance with the literature review and analysis, the factors attributed to the impacts of the WHL inscription are summarised into four domains: social and cultural, economic, environmental and political (Table 1). On the basis of this theoretical framework, the impacts of the WHL inscription are conceptualised.

\section{Research methodology and data}

\subsection{Case study: Kaiping Diaolou and Villages}

The WHS of Kaiping Diaolou and Villages is located southwest of the Pearl River Delta in Guangdong Province. Diaolou is the main architectural form with a multi-storey tower type, whose designs are used for defence and residence. In the 19th and 20th centuries, the threats of bandits and floods in Kaiping were serious. Thus, Kaiping immigrants, who usually worked as coolies (labourers) overseas, sent designs drawn by foreign designers and money back home to build Diaolou to protect their families. Figure 1 shows that Diaolou combines the functions of living with defence against banditry and protection against floods (Urban Planning and Design Center of Peking University, 2006). The architecture displays a complex and flamboyant fusion of Chinese and Western structural and decorative forms, which reflect the close links between overseas Kaiping and their ancestral homes (Urban Planning and Design Center of Peking University, 2006).

A total of 1.833 Diaolou buildings are located in Kaiping, which are distributed in thousands of villages among 15 towns. The number of Diaolou buildings in the core area of the heritage site comprise $12.6 \%$ of the total Diaolou buildings (Cheng \& Zhang, 2013). Figure 2 shows the core areas and buffer zones of Kaiping Diaolou and Villages. Nominated areas spread across Sanmenli, Zili, Jinjiangli and Majianglong villages, along with Fangshi Denglou (light tower), with a total area of approximately 372 kilometres. Table 2 presents the features of the four villages.

Table 1. Factors on the impacts of the WHL inscription

\begin{tabular}{|c|c|c|}
\hline Dimensions & Sub-dimensions & Sources \\
\hline \multirow[t]{6}{*}{ Social and cultural } & A sense of belonging & (Jimura, 2011) \\
\hline & Promotion of community cohesion & $\begin{array}{l}\text { (ICOMOS International Committee on Cultural } \\
\text { Tourism, 1999) }\end{array}$ \\
\hline & Revitalisation and education of local culture & (Airey \& Shackley, 1998; Evans, 2002) \\
\hline & Increase of congestion & (Jones et al., 2017; Melanie, 2002) \\
\hline & Improvement of infrastructure caused by tourism & (Naudé \& Saayman, 2005) \\
\hline & $\begin{array}{l}\text { Damages to heritage authenticity and integrity } \\
\text { (e.g. commercialisation) }\end{array}$ & (Caust \& Vecco, 2017; Kolar \& Zabkar, 2010) \\
\hline \multirow[t]{3}{*}{ Economic } & Increase of tourism development (e.g. tourists) & $\begin{array}{l}\text { (Caust \& Vecco, 2017; Jones et al., 2017; Parga Dans \& } \\
\text { Alonso González, 2019; Wang et al., 2015; Yang et al., } \\
\text { 2010) }\end{array}$ \\
\hline & Improvement of other industries & (Andereck \& Vogt, 2000) \\
\hline & Increase of residents' income and employment & (Andereck \& Vogt, 2000) \\
\hline \multirow[t]{4}{*}{ Environmental } & Promotion of environmental protection & (Wang \& Bramwell, 2012) \\
\hline & Behaving in an environment-friendly manner & (Wang et al., 2015) \\
\hline & Exceeding the environmental bearing capacity & $\begin{array}{l}\text { (Yang et al., 2010; UNESCO World Heritage Centre, } \\
\text { 2017) }\end{array}$ \\
\hline & $\begin{array}{l}\text { Damages to the environment (e.g. garbage, } \\
\text { artificial landscape) }\end{array}$ & (Caust \& Vecco, 2017) \\
\hline \multirow[t]{3}{*}{ Political } & Strategies and plan & (Bianchi, 2002; Shackley, 1998; Wager, 1995) \\
\hline & Engagement of different organisations & (Jones et al., 2017) \\
\hline & Community participation & (Luo, Zhang, Hu, \& Wang, 2016; UNESCO, 2012) \\
\hline
\end{tabular}




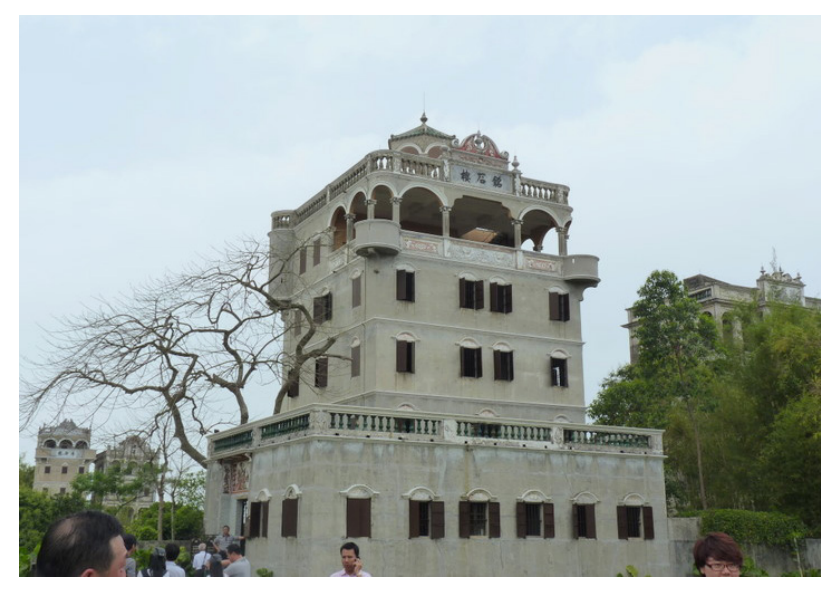

Figure 1. Architectural style of Diaolou (source: field survey)

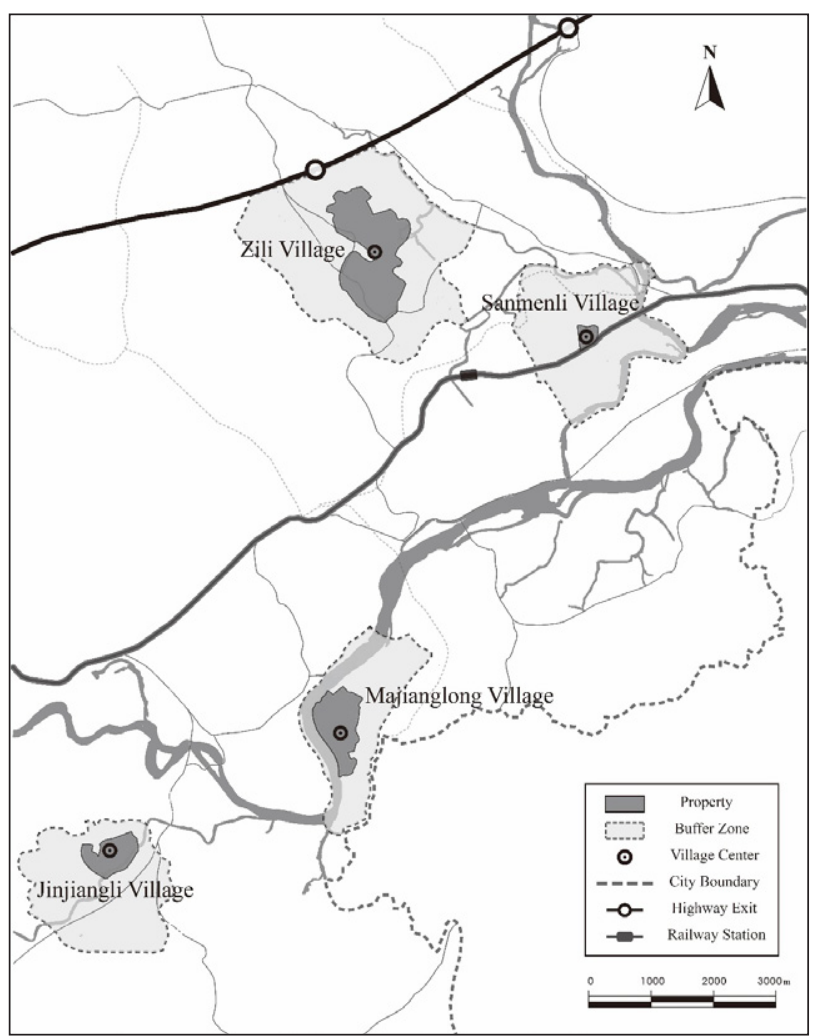

Figure 2. Core area and buffer zones of Kaiping Diaolou and Villages (source: the inscription text of Kaiping Diaolou and Villages)
In this study, the impacts of the WHL inscription is examined from residents' perspective. Kaiping Diaolou and Villages is chosen because of four reasons. Firstly, the city of Kaiping does not have any other international-level title except the WHS. WHS is the most popular brand for Kaiping, which has a far-reaching impact on the local area. From this viewpoint, Kaiping Diaolou and Villages is a typical case study. Secondly, from the beginning of preparation in 2000 to the successful WHL inscription in 2007, the Kaiping government has spent eight years doing considerable preparation (e.g. infrastructure construction, Diaolou repair, environmental improvement and inviting experts to investigate). Local residents had known about the inscription for a very long time, which gave them a deep understanding about the values of WHS. Thirdly, Kaiping Diaolou and Villages encompass a heritage site and is made up of communities of local residents. Most of the Diaolou buildings in Kaiping were built from the late 19th century to the early 20th century through remittances of overseas Chinese. Thus, most of the properties are privately owned. Some property owners live in the villages, whereas others already migrated to foreign countries. To obtain a trusteeship of Diaolou, the local government exerted great efforts to verify ownership and contact and negotiate with property owners. The characteristics of community heritage and frequent interaction between the government and villagers led to the deep perceptions towards the WHL inscription among the residents. Consequently, they developed a great understanding about the value of a WHS. Finally, the site of Kaiping Diaolou and Villages includes four core areas, in which the number of Diaolou buildings, their values and tourism development differ from one another. Examining the different impacts produced by the WHL inscription among the core areas will be helpful. In light of these considerations, the WHS of Kaiping Diaolou and Villages is chosen as an ideal case study for examining the impacts of the WHL inscription.

\subsection{Interview survey}

This study analysed the impacts of WHL inscription by exploring residents' understanding and thoughts about it. Semi-structured interview was employed because it is useful when partial knowledge exists about the topics

Table 2. Comparison of four villages (source: the inscription text of Kaiping Diaolou and Villages)

\begin{tabular}{|c|c|c|c|c|l|}
\hline Name & $\begin{array}{c}\text { Upper } \\
\text { administrative } \\
\text { area }\end{array}$ & $\begin{array}{c}\text { Core } \\
\text { area } \\
\left(\mathrm{hm}^{2}\right)\end{array}$ & $\begin{array}{c}\text { Buffer zone } \\
\text { area } \\
\left(\mathrm{hm}^{2}\right)\end{array}$ & $\begin{array}{c}\text { Number of } \\
\text { Diaolou in } \\
\text { core area }\end{array}$ & Features \\
\hline Sanmenli & Chikan Town & 0.048 & 705 & 1 & $\begin{array}{l}\text { The village has the oldest Diaolou building in Kaiping: } \\
\text { Yinglong Lou, which was built during the Ming Dynasty }\end{array}$ \\
\hline Zili & Tangkou Town & 252 & 988 & 16 & $\begin{array}{l}\text { The village has well-preserved Diaolou clusters, and the } \\
\text { landscape of the village is integral }\end{array}$ \\
\hline Jinjiangli & Xiangang Town & 16.9 & 628 & 3 & $\begin{array}{l}\text { The village has 'the first building in Kaiping' (Ruishi Lou), } \\
\text { and the ecological environment is harmonious }\end{array}$ \\
\hline Majianglong & Baihe Town & 103 & 417 & 15 & $\begin{array}{l}\text { The Diaolou buildings are covered in the bamboo forest, } \\
\text { and the village has a traditional Chinese village landscape } \\
\text { fronting water with hills on the back }\end{array}$ \\
\hline
\end{tabular}


under investigation, although further details are needed (Wilson, 2013). The theoretical framework obtained above can provide the predefined questions about the impacts of WHL inscription on the community, but special problems in Kaiping Diaolou and Villages remain unknown. Therefore, semi-structured interview can provide the reviewers the opportunity to raise new important factors through open-ended questions (Wilson, 2013).

Respondents were chosen based on the following two criteria. First, they needed to have experienced the process of the WHL inscription. Second, they needed to live in four core areas of the properties. Under these conditions, the respondents could observe and understand directly the impacts before and after the WHL inscription. According to these two criteria, 32 local residents ( 8 residents in each village) were chosen for interview, and each interview lasted between one and two hours. Questions of the in-depth interview were developed based on the factors summarised in Table 1. For example, residents were asked what are the social and cultural impacts of the WHL inscription (e.g. strengthening a sense of belonging, improving the cohesiveness of local communities, improving cognition of local culture, receiving education on local culture or others). If a type of impact was confirmed, the interviewee was asked to describe specific changes and feelings. The materials of the interview survey were all recorded for the following content analysis.

\subsection{Content analysis}

Content analysis was used in this study to frame the impacts of the WHL inscription from residents' perspective. Content analysis is defined as 'a research technique for making replicable and valid inferences from texts (or other meaningful matter) to the contexts of their use' (Krippendorff, 2004). Bengtsson (2016) referred that 'in contrast to other qualitative research methods, content analysis is not linked to any particular science, and there are fewer rules to follow, therefore, the risk of confusion in matters concerning philosophical concepts and discussions is reduced. In addition, content analysis is beneficial for researchers to understand special phenomena according to replicable inferences from studied materials (Krippendorff, 2004). These special phenomena include the origins and processing of sub-dimensions (Griffin, 2013). This method can be used to analyse all types of written materials such as deep interviews, open-ended questions, observations of constitutions and even films to provide an unbiased and objective analysis (Burnard, 1991; Krippendorff, 2004; Wann-Hansson, Hallberg, Klevsgård, \& Andersson, 2005). Following the method introduced by Bengtsson (2016), four steps of content analysis are used in the current study to analyse the materials of in-depth interviews. The steps are decontextualisation, recontextualisation, categorisation and compilation.

In this study, the detailed steps about content analysis are described as follows.

The first step is decontextualisation, which is to label meaning units with a code. Factors of dimension and subdimension were in accordance with the theoretical framework in Table 1. Meaning units were obtained based on the semi-structured interview. If a type of impact emerged in the materials of the semi-structured interview, it was marked once with a code. The second step is recontextualisation, which is to check if all the meaning units related to the impacts of the WHL inscription in Kaiping Diaolou and villages have been covered (Burnard, 1991). The third step is categorisation, which is to identify themes and categories. Dimensions, sub-dimensions and meaning units are identified and classified into different categories. In the current study, meaning units with synonymous descriptions were merged and classified into sub-dimensions. During this process, thematic analysis was used (Braun \& Clarke, 2006). Then, the sub-dimensions were classified into four dimensions, social and cultural, economic, environmental and political. The last stage is compilation,

Table 3. Content analysis sample (source: authors)

\begin{tabular}{|c|l|l|l|}
\hline \multicolumn{1}{|c|}{ Dimension } & \multicolumn{1}{|c|}{ Sub-dimensions } & \multicolumn{1}{|c|}{ Meaning unit } & \multicolumn{1}{c|}{ Detailed descriptions from semi-structured interview } \\
\hline $\begin{array}{l}\text { Social and } \\
\text { cultural impacts }\end{array}$ & $\begin{array}{l}\text { Cognition and } \\
\text { education of local } \\
\text { culture }\end{array}$ & $\begin{array}{l}\text { Understanding the } \\
\text { culture and history of } \\
\text { overseas Chinese }\end{array}$ & $\begin{array}{l}\text { Overseas Kaiping worked as coolies, and they engaged in the } \\
\text { construction in the USA and Canada } \\
\text { Although they worked hard, they still sent back money to build } \\
\text { Diaolou because of their Chinese traditional concept }\end{array}$ \\
\cline { 3 - 4 } & $\begin{array}{l}\text { Learning the reasons for } \\
\text { Diaolou construction }\end{array}$ & $\begin{array}{l}\text { Diaolou was useful to defend floods and banditry } \\
\text { Diaolou was also a reflection of the symbol of wealth of the } \\
\text { overseas }\end{array}$ \\
\cline { 3 - 5 } & $\begin{array}{l}\text { Understanding the } \\
\text { architectural values of } \\
\text { Diaolou building }\end{array}$ & $\begin{array}{l}\text { Diaolou was designed with the combination of traditional } \\
\text { Chinese and Western architectural features } \\
\text { Diaolou was a kind of architecture with both practicality and } \\
\text { beauty }\end{array}$ \\
\cline { 2 - 4 } & $\begin{array}{l}\text { Enhancement } \\
\text { of the sense of } \\
\text { belonging }\end{array}$ & $\begin{array}{l}\text { Being proud of the } \\
\text { hometown }\end{array}$ & $\begin{array}{l}\text { After the WHL inscription, Diaolou became being famous, } \\
\text { residents were proud their hometown being inscribed as a WHS }\end{array}$ \\
\cline { 3 - 5 } & $\begin{array}{l}\text { Willingness to live and } \\
\text { work at home }\end{array}$ & $\begin{array}{l}\text { Residents willingness to live in Kaiping Diaolou WHS was } \\
\text { mainly decided by job opportunities which were usually related } \\
\text { with tourism industry }\end{array}$ \\
\hline
\end{tabular}


which explores the essence of the phenomenon (Bengtsson, 2016). This procedure was conducted by discussions with local officials in Kaiping and experts in Peking University.

Table 3 presents an example of the process of content analysis. In the following section of analysis and findings, the detailed descriptions of impacts brought by the WHL inscription were summarised by first-level dimension, sub-dimension and meaning unit. The differences among four core villages are provided in tables.

\section{Impacts of the WHL inscription}

\subsection{Demographic profile of respondents}

The demographic profile of the 32 respondents are listed in Table 4.

\subsection{Social and cultural dimension}

(1) Promotion of the local cultural cognition

Twenty-three respondents, eight from Zili, seven from Jinjiangli and eight from Majianglong, agreed that the WHL inscription promoted their local cultural cognition by improving their understanding about the culture and history of overseas Chinese. Before the WHL inscription, residents knew little about the culture and history of overseas Chinese. Such a view was changed by the branding of the WHS (e.g. museums built for the WHL inscription). Diaolou buildings witnessed a special history of overseas Chinese, especially overseas Kaiping. In the early 20th century, people migrated abroad under the pressure of living and worked hard as coolies. In this way, overseas Chinese greatly contributed to global development. For example, Chinese labours engaged in the construction of the Union Pacific Railroad and Central Pacific Railroad, which connected the United States and Canada. In these projects, a large number of overseas Chinese died because of bad weather and serious working conditions. On the one hand, although overseas Chinese worked very hard abroad, they still sent back their money home to build Diaolou to protect their families against floods and bandits. On the other hand, overseas Chinese returned home and spent much money to build Diaolou, which reflected the traditional local concept of 'returning to one's hometown in silken robes' (yi jin huan xiang). Many cultural antiques (e.g. phonographs, crystal lamps, passports and photographs) found in Diaolou indicated that overseas Kaiping brought Western commodities and lifestyle to China, but they still abided by Chinese traditional feudal etiquette. Cultural conflict and integration between China and Western countries manifested itself in Kaiping Diaolou. The culture and history of overseas Chinese and their contributions to the world were recorded through the heritage. However, the situation in Sanmenli was different. Here, only two respondents indicated that the WHL inscription improved their cognition of overseas Chinese culture and history because few Diaolou and overseas Chinese lived in Sanmenli. Yinglong Lou, the only Diaolou in Sanmenli built during the Ming Dynasty, was constructed by raising funds from all the villagers at the time. No relationship exists between this Diaolou and overseas Chinese.

All the respondents agreed that the WHL inscription improved their understanding of the two main reasons of Diaolou construction. The first reason was to defend the residents from floods and banditry. Kaiping was located in a low terrain with densely covered river, so it usually suffered from floods. In addition, in 1912-1949 (zhong hua min guo), banditry was so rampant in the country that numerous tragedies occurred. Under such conditions, overseas Chinese began to send money home to build Diaolou to protect their families. This factor contributed to the defence characteristics of the Diaolou. The second rea-

Table 4. Description of respondents (source: field survey)

\begin{tabular}{|c|c|c|c|c|c|}
\hline \multicolumn{2}{|c|}{ Socio-demographic variables } & Percent & \multicolumn{2}{|c|}{ Socio-demographic variables } & Percent \\
\hline \multirow[t]{2}{*}{ Gender } & Male & 66.7 & \multirow{5}{*}{$\begin{array}{c}\text { Educational } \\
\text { level }\end{array}$} & Primary school & 50 \\
\hline & Female & 33.3 & & Junior high school & 26.7 \\
\hline \multirow[t]{2}{*}{ Minority } & Han people & 100 & & Senior high school & 16.7 \\
\hline & other & 0 & & Bachelor & 6.7 \\
\hline \multirow[t]{5}{*}{ Age } & $0-20$ & 3.3 & & Master or higher & 0 \\
\hline & $21-40$ & 26.7 & \multirow[t]{4}{*}{ Occupation } & Farmer & 56.7 \\
\hline & $41-50$ & 23.3 & & Private business owner & 13.3 \\
\hline & $51-60$ & 26.7 & & Tourism service worker & 16.7 \\
\hline & 60 and above & 20 & & Others & 13.3 \\
\hline \multirow[t]{2}{*}{ Household registration } & Local place & 90 & \multirow{6}{*}{$\begin{array}{l}\text { Household } \\
\text { income }\end{array}$} & Less than 10 thousand yuan & 23.3 \\
\hline & Other places & 10 & & & \\
\hline \multirow[t]{4}{*}{ Core area } & Sanmenli & 25 & & \multirow[t]{2}{*}{11 thousand-30 thousand yuan } & \multirow[t]{2}{*}{36.7} \\
\hline & Zili & 25 & & & \\
\hline & Jinjiangli & 25 & & 31 thousand -50 thousand yuan & 23.3 \\
\hline & Majianglong & 25 & & 51 thousand yuan or more & 16.7 \\
\hline
\end{tabular}


son was the localism of overseas Chinese. After earning money, returning home to build houses was considered a highly honourable effort by the traditional Chinese people. This condition made Diaolou became a symbol of wealth.

Several respondents (seven from Zili, six from Jinjiangli and seven from Majianglong) said that they deeply understood the values of Diaolou through the WHL inscription. Before the WHL inscription, they did not think that Diaolou had a heritage value because they perceived it as a usual phenomenon. After the WHL inscription, residents began to understand the values of Diaolou, which is a special architectural form. Influenced by Western culture, overseas Kaiping designed the Diaolou with the combination of traditional Chinese and Western architectural features. The ancient Greek, ancient Rome and Gothic architectural styles, among others, were transmitted to Chinese vernacular architecture. Given that the main use of Diaolou was to protect people from floods and banditry, the Diaolou appearance was characterised by defensive forms, such as high floors, thick concrete walls, iron fence windows and searchlights. The whole landscape of Kaiping consisted of Diaolou buildings, bamboo forests, ponds, banyan trees and hills, indicating the traditional environmental consciousness and Chinese feng shui concept. Being different from the other three villages, Yinglong Lou in Sanmenli had great historical value because it was the only brick-wood Diaolou structure in Kaiping and was the oldest Diaolou with a history of over 400 years. Villagers used to perform ancestor worship ceremonies in the area. Five respondents from Sanmenli expressed that they learned more about the values of Yinglong Lou and were proud of it.

(2) Enhancement of the sense of belonging

All respondents referred that the WHL inscription instilled in them a strong sense of pride in their hometown. Because of the strong influence and public recognition of the WHS, the world cultural heritage of Kaiping Diaolou and Villages had synonymous with Kaiping. Similar to the findings of(Jimura, 2011), residents in Kaiping Diaolou WHS were very proud that their hometown could be inscribed as a world cultural heritage site and that it became a famous tourist attraction.

Being different from Japanese residents whose willingness to live in the WHS is decided by the convenience and comforts of daily life and European people who are proud of the inconvenience caused by WHSs (Jimura, 2011), residents' willingness to live in Kaiping Diaolou WHS was mainly decided by job opportunities. After the WHL inscription, the development of the tourism industry in Zili, Jinjiangli and Majianglong provided several job opportunities for local residents, such as opening restaurants and selling souvenirs. Therefore, some respondents (eight from Zili, four from Jinjiangli and five from Majianglong) expressed their willingness to live and work in their hometown. However, the condition in Sanmenli was markedly different. It only has one Diaolou building and was not opened as a tourist area. Except for agriculture, few job opportunities were available for the residents. Only two respondents stated that they would stay home. Other respondents declared that they would leave home and go to cities to find jobs. This result reflected the fact that survival remains the most important task for residents in Chinese rural areas.

(3) Enhancement of community cohesion

Most respondents in the four core areas confirmed that the WHL inscription of Kaiping Diaolou and Villages improved community cohesion by developing a sense of ownership and neighbourhood relations. Community cohesion is an important content required by ICOMOS (ICOMOS International Committee on Cultural Tourism, 1999). The WHL inscription needs community participation in relating affairs (e.g. heritage protection and development, sharing ticket bonuses and negation about heritage ownership), in which local residents need to discuss and trust each other and make a final decision together. Therefore, neighbourhood relations were improved through these affairs. Respondents' perceptions were fairly similar in the four core areas.

(4) Improvement of infrastructure

Most respondents agreed that to inscribe the heritage on the WHL, the government greatly improved the public infrastructure for the villages. These improvements made the communities much safer and more liveable than before. The main improvements involved three main aspects: improving roads (e.g. paving and widening and building new roads), improving security (e.g. equipping with cameras and employing security guards) and construction of public toilets. Improvement in infrastructure brought about by tourism, as demonstrated by Naudé and Saayman (2005), had not existed in the four villages of Kaiping Diaolou WHS.

(5) Damage to social community environment

The negative impacts towards the social and cultural dimension of the WHL inscription are only related to the public environment damages. Given the rapid development of tourism, instances of theft occurred in the villages. Although most tourists followed the law, some tourists entered residents' yards to steal fruits. Given that this situation was not very serious, only a small number of respondents (two from Zili and one from Jinjiangli) expressed that they confronted this issue. Other damage like congestion (Jones et al., 2017) and destruction of heritage authenticity and integrity (Caust \& Vecco, 2017) did not exist in Kaiping Diaolou WHS.

The results in Table 5 indicate that the local cultural cognition, sense of belonging, community cohesion and infrastructure construction were central to social and cultural themes throughout the WHL inscription, and these two factors were positively improved by the designation of Kaiping Diaolou and Villages. The development history and existing heritage resources of each village caused different types of cultural cognition and senses of belonging in the four core areas. 
Table 5. Impacts of the WHL inscription from the social and cultural aspect (source: field survey)

\begin{tabular}{|c|c|c|c|c|c|c|}
\hline & Sub-dimensions & Meaning unit & Sanmenli & Zili & Jinjiangli & Majiang-long \\
\hline \multirow[t]{10}{*}{ Benefits } & \multirow{3}{*}{$\begin{array}{l}\text { Cognition and } \\
\text { education of local } \\
\text { culture }\end{array}$} & $\begin{array}{l}\text { Understanding the culture and history } \\
\text { of overseas Chinese }\end{array}$ & 2 & 8 & 7 & 8 \\
\hline & & $\begin{array}{l}\text { Learning the reasons for Diaolou } \\
\text { construction }\end{array}$ & 8 & 8 & 8 & 8 \\
\hline & & $\begin{array}{l}\text { Understanding the architectural values } \\
\text { of Diaolou building }\end{array}$ & 5 & 7 & 6 & 7 \\
\hline & \multirow{2}{*}{$\begin{array}{l}\text { Enhancement of the } \\
\text { sense of belonging }\end{array}$} & Being proud of the hometown & 8 & 8 & 8 & 8 \\
\hline & & Willingness to live and work at home & 2 & 8 & 4 & 5 \\
\hline & \multirow{2}{*}{$\begin{array}{l}\text { Promotion of } \\
\text { community cohesion }\end{array}$} & Improving neighbourhood relations & 4 & 5 & 5 & 6 \\
\hline & & Sense of ownership & 6 & 7 & 6 & 8 \\
\hline & \multirow{3}{*}{$\begin{array}{l}\text { Improvement of } \\
\text { infrastructures }\end{array}$} & Improving the roads & 5 & 7 & 7 & 6 \\
\hline & & Improving the security & 6 & 8 & 7 & 8 \\
\hline & & Construction of public toilets & 8 & 8 & 8 & 8 \\
\hline Costs & $\begin{array}{l}\text { Damage to social } \\
\text { community } \\
\text { environment }\end{array}$ & Increasing theft & 0 & 2 & 1 & 0 \\
\hline
\end{tabular}

\subsection{Economic dimension}

(1) Increase in tourism development

Respondents (eight from Zili, seven from Jinjiangli and six from Majianglong) felt that the number of visitors rapidly increased after Kaiping Diaolou and Villages was declared as a WHS in 2007. The WHL inscription has the 'touristenhancing effect' (Su \& Lin, 2014) and is a new form of income generation (Caust \& Vecco, 2017). Figure 3 indicates that the number of visitors and tourism income of Kaiping mainly remained unchanged before 2007. However, after the WHL inscription in 2007, the number of tourism sharply increased by $35.6 \%$ and tourism income increased by $37.3 \%$ in the following year. From 2007 to 2015 , the average annual growth rate of tourist arrivals and the tourism income was $12.8 \%$ and $21.4 \%$, respectively. Similar situations were also observed in most WHSs (Jones et al., 2017; Wang et al., 2015). However, tourism development in the four core areas was different because it mainly concentrated in Zili, Jinjiangli and Majianglong. The three villages were suitable for visiting as they had diversified Diaolou

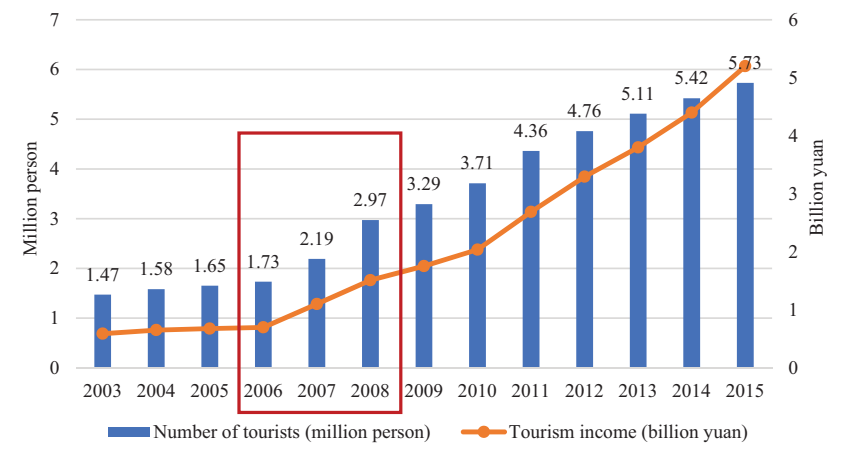

Figure 3. Number of tourists and tourism income in Kaiping from 2003 to 2015 (source: Statistics Communique on National

Economic and Social Development of Kaiping, 2003-2015) architecture and landscapes. Many movies were also shot there, and tourists visited Diaolou and the filming locations. Compared with other villages, most respondents did not feel positive about the changes in visitors. Sanmenli was a special area that had not been opened as a tourism spot. Although Yinglong Lou is the oldest Diaolou building in Kaiping, it is characterised by a low quality of ornamentation (Figure 4). Tourists were not permitted to enter the building because it was unfit for visits and needed repair. Although some visitors were allowed to enter, they looked at Yinglong Lou and left without spending money. Most respondents in Sanmenli revealed jealous feelings towards the tourism income of the other three villages.

Respondents (eight from Zili, six from Jinjiangli and seven from Majianglong) declared that holding tourism activities attracted more tourists. To brand the WHS of Kaiping Diaolou and Villages and attract tourists, the local government held the annual Cultural Tourism Festival, which included the performance of folk customs, introduction to Diaolou history, display of local food, tourism investment forums and other related activities. The cul-

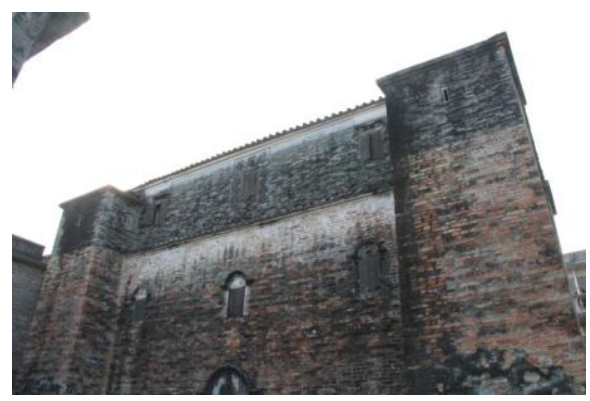

Figure 4. Yinglong Lou in Sanmenli village (source: field survey) 
tural events held in WHSs played an important role in attracting visitors (Cuccia, Guccio, \& Rizzo, 2016). However, as the heritage resource in Sanmenli was scarce, no festival activities had ever been held there. Therefore, no respondents in Sanmenli referred to this impact.

To develop the tourism industry, the local government also set up a Kaiping Diaolou Tourism Company and entrusted it with the responsibility of the tourism management of Kaiping Diaolou and Villages. Kaiping Diaolou Tourism Company established branch offices in Zili, Jinjiangli and Majianglong, but not in Sanmenli because the tourism company considered the village unsuitable for tourism development. A special website was also set up by the tourism company to brand the WHS Kaiping Diaolou and Villages, where related heritage knowledge and scenic spots were introduced. All the villages, except for Sanmenli, were introduced in detail as scenic spots. Therefore, the respondents in Zili, Jinjiangli and Majianglong agreed that the tourism company contributed considerably to improve the local tourism development, whereas the respondents in Sanmenli envied the tourism development in the other three villages and eagerly hoped that the government would support and improve their local tourism.

(2) Increase in villagers' income and employment All the respondents in Zili, Jinjiangli and Majianglong claimed that WHL increased their income by allocating ticket income, whereas respondents in Sanmenli showed

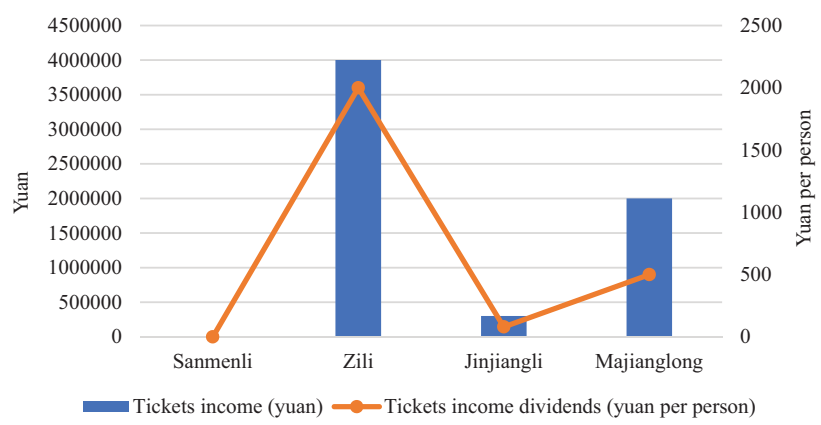

Figure 5. Ticket income and ticket income dividends in Kaiping Diaolou and Villages (source: field survey) that they did not receive any ticket income. The detailed values of the four core areas are shown in Figure 5. The tourism company accounted for $90 \%$ of the total tourism income, whereas the community accounted for $10 \%$. Residents who had registered residences in Zili, Jinjiangli and Majianglong could share $10 \%$ of the tickets dividends together. In 2011, the ticket income of Zili, Jinjiangli and Majianglong was 4, 3 and 2 million yuan, respectively. Each villager was allocated a ticket dividend of approximately 2,000, 80 and 500 yuan. This form of income increased the sources of income of residents because they could engage in their own jobs at the same time. By contrast, Sanmenli was not a scenic spot and did not receive tickets. Hence, they were not allocated any dividend.

Tourism can produce new job opportunities (Caust \& Vecco, 2017; F. Li, Wang, Y. Li, \& Zhou, 2017). The respondents revealed that villagers' employment increased by participating in tourism-related services (e.g. opening restaurants, hotels and souvenir shops). Five respondents showed that the number of tourists in Zili was larger in comparison with other villages. As shown in Figure 6, Zili was fitted for tourism development because of its rich heritage resources and beautiful landscapes. In addition, the famous Chinese movie Let the Bullets Fly was shot there. Hence, the movie locations attracted travellers. The large number of visitors required additional tourism services, which could provide diversified job opportunities for locals. Some residents could even earn enough money to support their families by doing tourism services. Thus, tourism in Zili was stable, and the income from tourismrelated jobs was high. These findings were different from the conclusion that tourism is fragile and tourism-related jobs have 'low-paid' and 'highly seasonal' characteristics (Gordon \& Brian, 2000). Two respondents in Jinjiangli and two in Majianglong said that the number of visitors in the two villages increased but remained less than visitors in Zili. Tourism in Jinjiangli and Majianglong was seasonal. Most visitors went there during holidays and weekends, and visitors on normal days were few. Unstable tourist flow made the residents who participated in tourism-related jobs engage in other jobs at normal times. In Sanmenli, no respondent participated in tourism services.

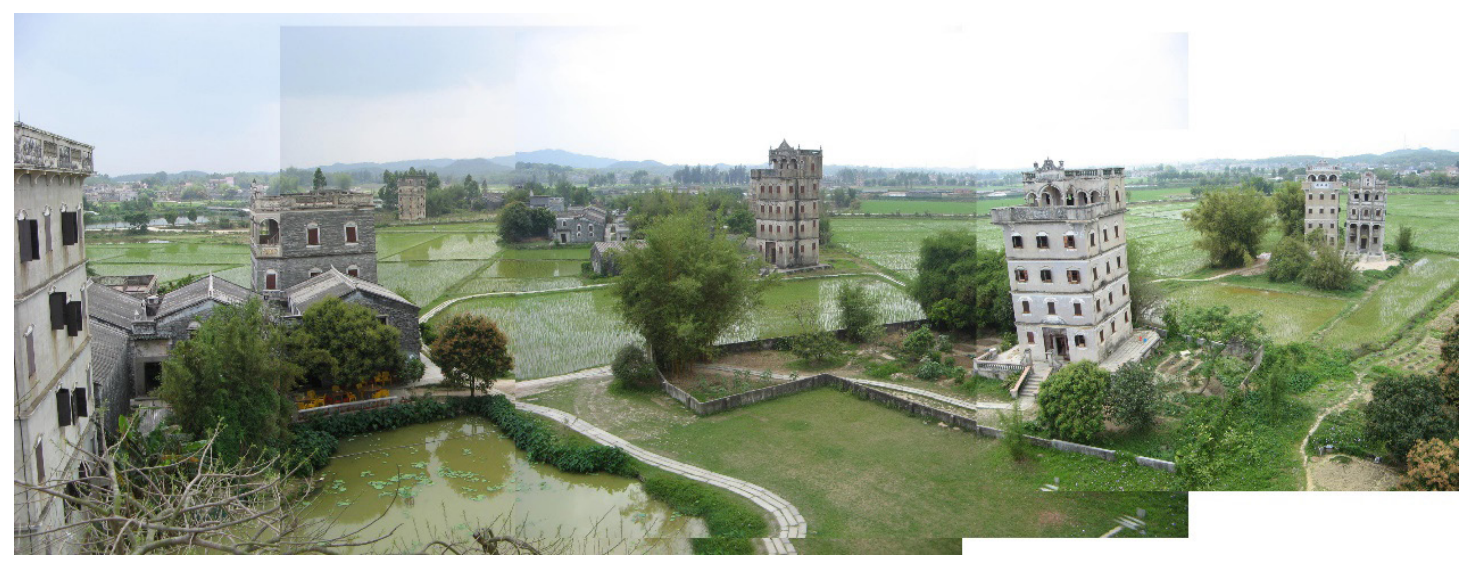

Figure 6. Landscape of Zili village (source: field survey) 
The villagers' income and employment also increased owing to tourism companies. Respondents revealed that local residents were mainly hired as service workers, such as cleaners, security guards and Diaolou building keepers, by the tourism company. The numbers of these posts in the four core areas were 4, 30, 10 and 24, respectively (Figure 7). To highlight fairness, these posts could be occupied in rotation by local villagers. During the interview, nine respondents (two in Sanmenli, three in Zili, two in Jinjiangli and two in Majianglong) were employed as service workers. They mentioned that they obtained stable monthly salaries and their income improved by doing these jobs. Studies usually focused more on the tourism-related jobs brought by individual businesses (e.g. shops and restaurants) (Jha, 2005; Newby, 1990) and less on job opportunities provided by the manager of WHS. Income from these types of job was more stable than that from individual businesses, but it was also not as profitable as that during peak seasons.

(3) Solving the Diaolou property rights problem

Respondents showed that the Diaolou property rights problem was solved by the trusteeship system. Reasonably solving the property rights of heritage in sites where living communities are located is necessary for the sustainable development and management of WHSs. However, this problem was seldom studied in the existing literature. The trusteeship system was first applied in the management of WHSs in China. Based on the agreement of the property owners, the government took over the development and management rights of Diaolou buildings by giving monetary compensation or new apartments to the property owners. However, the ownership of Diaolou buildings still rested with the former owners. By holding the development and management rights of Diaolou, the government could control the planning, protection and development of the entire WHS. The owners of Diaolou buildings initially distrusted the government and feared that the government would declare such buildings as public properties. Hence, they refused trusteeship. Through repeated, long communication and negotiation with the local government, most owners understood the advantages of the trusteeship system and finally agreed to transfer the management and development rights to the local government.

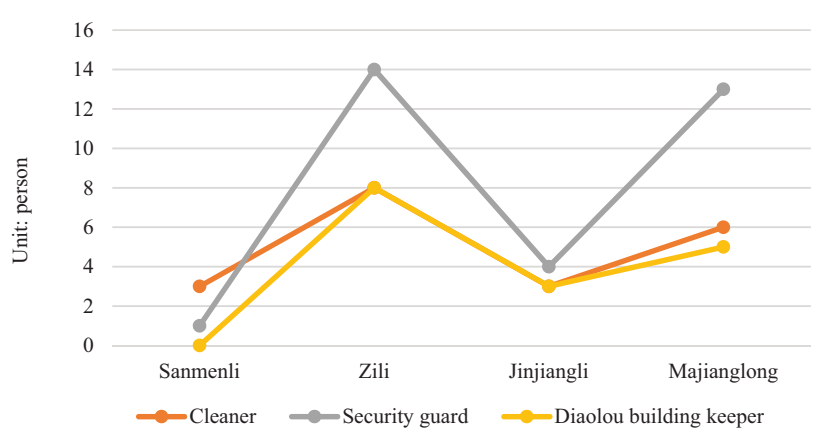

Figure 7. Number of service workers in the four core areas (source: field survey)
Four respondents stated that they obtained trustee fees of 80.000 yuan per year for 50 years, whereas two respondents chose new apartments instead of trustee fees. Most respondents (eight in Zili, seven in Jinjiangli and six in Majianglong) were greatly satisfied with the trusteeship system regardless of whether they were owners of Diaolou. They believed that the property rights problem was solved well and the rights of villagers were well protected. Yinglong Lou in Sanmenli was not under this system. Thus, no respondent from the area expressed ideas towards this dimension. The application of the trusteeship system on the management and development of WHSs could shed light on other WHSs in China.

(4) Worse tourism development than previous expectations The respondents mentioned that, although the number of visitors increased rapidly after the WHL inscription, it remained less than their previous expectation. Given that people consider that WHS has a high public profile and great recognition, they believed that the WHL inscription would attract a considerable number of tourists. However, they felt that the number of tourists after the WHL inscription was less than their previous expectation. All respondents in Sanmenli were angry because very few tourists visited Yinglong Lou; six respondents in Zili, six in Jinjiangli and six in Majianglong were unsatisfied with the insufficient number of tourists.

The consumption of tourists was also less than residents' previous expectation. Represented by the Old Town of Lijiang and Ancient City of Ping Yao, villages or towns in the heritage sites were suitable for tourism development. The primary elements of the tourism industry, such as food, recreation, transportation, shopping and accommodation, were easily found and developed in such a heritage site. However, the tourist attractions in Kaiping Diaolou and Villages were insufficient. Tourists could only visit certain Diaolou buildings. Sometimes, they only ate meals or bought local specialties and then left. In the interviews, respondents (seven in Zili, seven in Jinjiangli and six in Majianglong) wished that tourists would extend their stay at the destinations so that they would spend more money on recreation and accommodation. By contrast, eight respondents in Sanmenli wished that tourists would eat meals or buy goods there.

The respondents revealed that the government provides no preferential policy or support in improving residents' participation in the tourism industry. The local government had promised support to residents engaging in the tourism business, but no specific policy or project had been implemented. Respondents (eight in Sanmenli, six in Zili, seven in Jinjiangli and six in Majianglong) are satisfied with this situation. They strongly hoped that the local government could develop tourism projects and build facilities to attract additional tourists and make them stay longer than usual.

These findings indicated that residents pay much attention to tourism development and considered tourism a profitable industry. Regardless of the actual development of tourism, the residents usually felt it was not enough and wished for its improvement. 
(5) Unequal income and employment

Existing studies do not focus on the problem of inequality. Residents felt that the income and employment situation was unfair. Moreover, they felt that the allocation of ticket dividends was unfair. Sanmenli was an important part of the WHS, but it did not have tourism income and services. Eight respondents were unsatisfied because they were not allocated any ticket dividend. They wished that the lack of tourism in Sanmenli be supplemented by allocating a proportion of ticket income from the other three villages. Respondents (seven in Jinjiangli and eight in Majianglong) also felt unsatisfied because the $10 \%$ of the total ticket income shared by all the villagers was too low. They demanded an increase in the proportion of ticket income that went to the residents. By contrast, only two respondents in Zili thought that additional income should be given to them.

The respondents also felt that the position distribution of clericals in the tourism company was unfair. As indicated in Figure 8, the tourism company hired 98 clerical staff (45 in Zili, 13 in Jinjiangli and 40 in Majianglong) for administrative and management positions. However, only one clerical staff in Majianglong was a local resident. The rest of the clerical staff comprised nonlocal residents because local residents usually had a lower level of education in comparison with nonlocals. Respondents (two in Sanmenli, one in Zili and two in Majianglong) felt unsatisfied with this situation. The feeling of inequality in the community was harmful to the sustainable development of WHSs, which required the local government's attention.

(6) Unsolved Diaolou property rights problems

The local government did not completely solve the Diaolou property rights problem. The government only promoted the trusteeship system before the WHL inscription, but it did not respond to the willingness of residents to become trustees after the successful inscription, leading to complaints from residents. During the interviews, one respondent in Jinjiangli and another in Majianglong expressed that they wished to become Diaolou trustees, but they did not receive feedback from the local government.

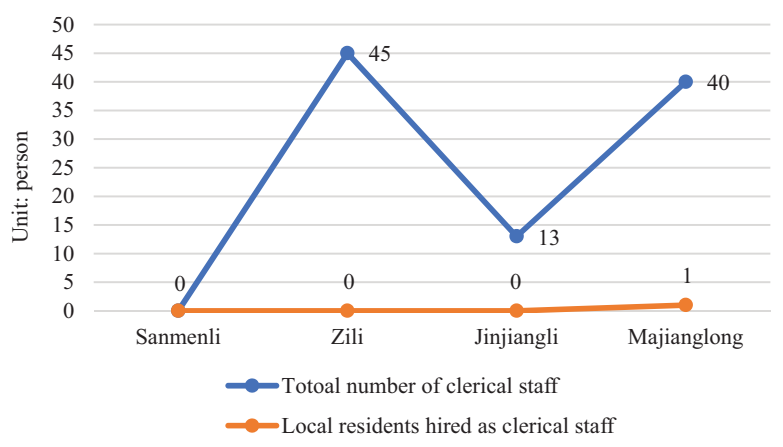

Figure 8. Total number of clerical staff and local residents hired as clerical staff (source: field survey)
Another problem was the property rights of Ruishi Lou. Ruishi Lou was very spectacular and is 'the first building in Kaiping' (Figure 9). The building was shared by different property owners living in different countries, but they did not reach an agreement on the government's trusteeship system. Therefore, Ruishi Lou was managed by one of the property owners living in Jinjiangli and was opened for visits by charging 20 yuan per visitor. It is the only Diaolou operated by a private owner in this WHS. Six respondents in Jinjiangli were extremely dissatisfied with the owner of Ruishi Lou. They declared that the profit of ticket sales should belong to all the villagers because Ruishi Lou was the first building in Kaiping, and it attracted many visitors despite the government's efforts towards the WHL inscription and the title of WHS. Heritage property rights were directly related to the economic benefits and costs of the residents. Thus, they seriously considered this problem.

As indicated in Table 6, the improvement of tourism development, increase in villagers' income and employment and solution to the problems of the heritage's property rights are central themes of the positive impacts before, during and after the WHL inscription. Moreover, the WHL inscription caused increased expectations in the economic benefits for residents, so the residents are likely to be disappointed with the actual outcomes. This scenario may lead to unfair feelings of residents, which requires the government's attention and action.

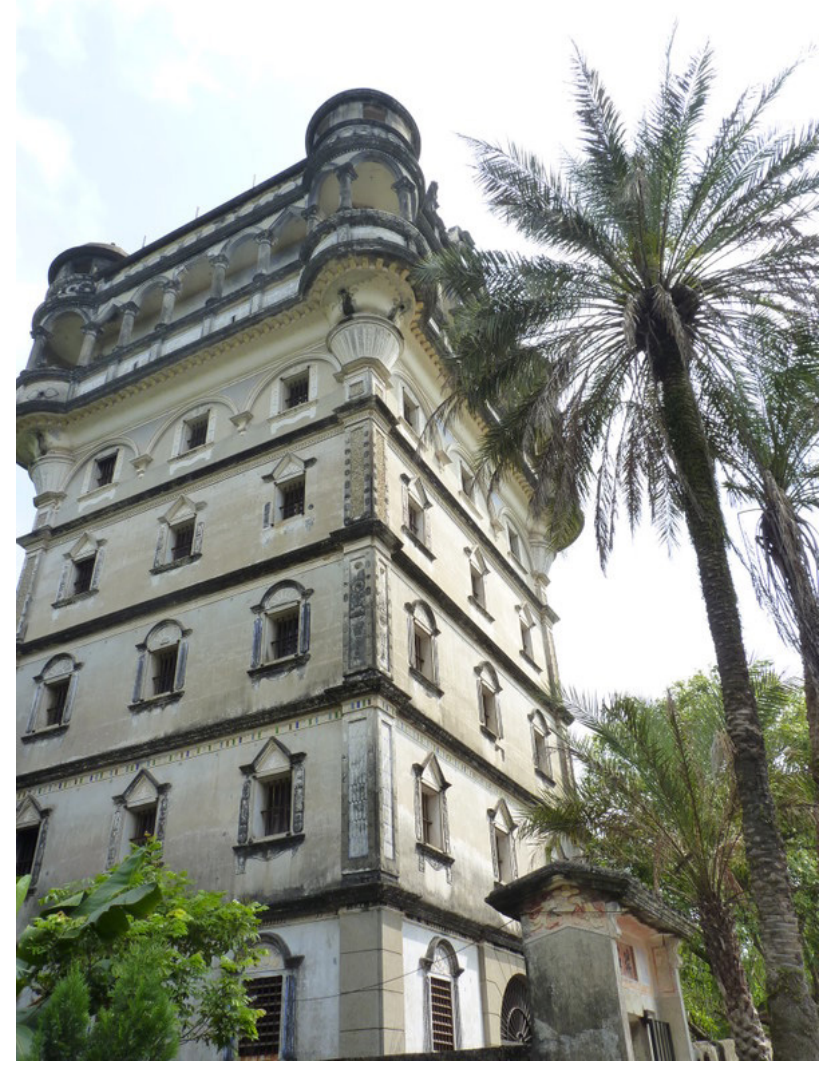

Figure 9. Ruishi Lou in Jinjiangli village (source: field survey) 
Table 6. Economic impacts of the WHL inscription (source: field survey)

\begin{tabular}{|c|c|c|c|c|c|c|}
\hline & Sub-dimensions & Meaning unit & Sanmenli & Zili & Jinjiangli & $\begin{array}{l}\text { Majiang- } \\
\text { long }\end{array}$ \\
\hline \multirow[t]{9}{*}{ Benefits } & \multirow{3}{*}{$\begin{array}{l}\text { Increase of tourism } \\
\text { development }\end{array}$} & Increasing the number of tourists & 2 & 8 & 7 & 6 \\
\hline & & Holding tourism activities & 2 & 8 & 6 & 7 \\
\hline & & Setting up tourism company offices & 0 & 8 & 8 & 8 \\
\hline & \multirow{3}{*}{$\begin{array}{l}\text { Increase of villagers' } \\
\text { income and employment }\end{array}$} & Obtaining ticket dividends & 0 & 8 & 8 & 8 \\
\hline & & Participating in tourism services & 0 & 5 & 2 & 2 \\
\hline & & $\begin{array}{l}\text { Being employed by the tourism } \\
\text { company }\end{array}$ & 2 & 3 & 2 & 2 \\
\hline & \multirow{3}{*}{$\begin{array}{l}\text { Solving the problem of } \\
\text { Diaolou's property rights }\end{array}$} & Getting trustee fees & 0 & 2 & 1 & 1 \\
\hline & & Changing new apartment & 0 & 1 & 1 & 0 \\
\hline & & $\begin{array}{l}\text { Being satisfied with the trusteeship } \\
\text { system }\end{array}$ & 0 & 8 & 7 & 6 \\
\hline \multirow[t]{7}{*}{ Costs } & \multirow{3}{*}{$\begin{array}{l}\text { Worse tourism } \\
\text { development than } \\
\text { previous expectation }\end{array}$} & Less tourists than expected & 7 & 6 & 6 & 6 \\
\hline & & Lower consumption of tourists & 8 & 7 & 7 & 6 \\
\hline & & $\begin{array}{l}\text { Receiving less supports for } \\
\text { participating in tourism services }\end{array}$ & 8 & 6 & 7 & 6 \\
\hline & \multirow{2}{*}{$\begin{array}{l}\text { Inequality of income and } \\
\text { employment }\end{array}$} & Unfair distribution of ticket dividends & 8 & 2 & 7 & 8 \\
\hline & & Unfair distribution of jobs & 2 & 1 & 0 & 2 \\
\hline & \multirow{2}{*}{$\begin{array}{l}\text { Unsolved problems of } \\
\text { Diaolou's property rights }\end{array}$} & Wishing to trustee Diaolou & 0 & 0 & 1 & 1 \\
\hline & & Problem of Ruishi Lou & 0 & 0 & 6 & 0 \\
\hline
\end{tabular}

\subsection{Environmental dimension}

(1) Improvement of physical environment

Most respondents showed that the WHL inscription improved the environment. With the declaration of the WHL inscription, the local government adopted several strategies to improve the physical environment. Before the WHL inscription, the sanitation conditions were poor because garbage and silt accumulated in the water (rivers, ponds and lakes), roads and neglected corners of the villages. To optimise the environment, the local government cleared up these areas and required the residents to protect the community environment collectively. Each village was allocated with several cleaners for the daily maintenance of environmental sanitation in each core area. Most of the respondents felt that these measures greatly improved the environment of the villages. This finding of Kaiping Diaolou WHS was noteworthy because existing studies usually focused on the environmental damage of tourism. Only Wang and Bramwell (2012) said that the environment was improved with strategic plans.

(2) Promotion of people's attention to the environment Respondents (five in Sanmenli, six in Zili, five in Jinjiangli and seven in Majianglong) felt that the WHL inscription promoted people's attention to the environment. Moreover, residents' attention to the environment was greatly improved because the local government continuously propagated the importance of environmental protection and required the residents to protect the environment. They were also willing to behave in an environmentally friendly manner because of the WHL inscription (Ma, Fan, \& Feng, 2017; Wang et al., 2015).
People's attention toward the environment was also improved by tourism development. Previously, residents were accustomed to the free-roaming backyard poultry and mess in the village. However, with the growing number of visitors attracted by the WHL inscription, they began to feel ashamed about letting the visitors see such messes. Residents are now concerned about their behaviours and keep poultry in cages and throw rubbish into trash cans. Therefore, tourism played an exposure effect on the residents. This effect was obvious in Zili, Jinjiangli and Majianglong where the number of tourists was high. Respondents (seven in Zili, six in Jinjiangli and seven in Majianglong) demonstrated this change of awareness. However, only one respondent in Sanmenli agreed with this promotion. Existing studies about the 'exposure effect' usually focused on the impacts of mega-events (Wang, Lin, \& Xia, 2012). This study demonstrated this effect in WHSs.

(3) Environmental destruction

Environmental destruction was a serious problem in WHSs (Caust \& Vecco, 2017; Wei, Gu, Wang, Yao, \& $\mathrm{Wu}, 2018)$. Increasing tourism development exerted negative impacts on the environment, such as noise and littering (Andriotis \& Vaughan, 2003). Respondents (two in Zili, one in Jinjiangli and one in Majianglong) felt that large numbers of visitors introduced noise and garbage pollution to the community, especially during peak seasons. Nevertheless, similar to the findings of Mihalik and Simoneita (1998), residents also revealed that the situation was not serious, and they did not consider it important. 
Table 7. Impacts of the WHL inscription from the environmental aspect (source: field survey)

\begin{tabular}{|c|c|c|c|c|c|c|}
\hline & Sub-dimensions & Meaning unit & Sanmenli & Zili & Jinjiangli & Majiang-long \\
\hline \multirow[t]{5}{*}{ Benefits } & \multirow{3}{*}{$\begin{array}{l}\text { Improvement of } \\
\text { environment }\end{array}$} & Cleaning the river and ponds & 8 & 8 & 8 & 8 \\
\hline & & Clearing up the solid waste & 7 & 8 & 8 & 8 \\
\hline & & Cleaning the roads and walls & 7 & 8 & 7 & 7 \\
\hline & \multirow{2}{*}{$\begin{array}{l}\text { Promotion } \\
\text { of people's } \\
\text { attention to the } \\
\text { environment }\end{array}$} & Being improved by the government propaganda & 5 & 6 & 5 & 7 \\
\hline & & Being improved by the tourism & 1 & 7 & 6 & 7 \\
\hline \multirow[t]{2}{*}{ Costs } & \multirow{2}{*}{$\begin{array}{l}\text { Environmental } \\
\text { destruction }\end{array}$} & Garbage dumping by local residents & 6 & 0 & 0 & 0 \\
\hline & & Environment problems caused by tourism & 0 & 2 & 1 & 1 \\
\hline
\end{tabular}

Environmental destruction was also caused by local residents. Six respondents in Sanmenli demonstrated that a villager dumped smelly garbage in his house. During the WHL inscription process, the leaders of the village communicated the problem with the house owner many times, but it remained unsolved. After the WHL inscription, given that Sanmenli was not a scenic spot, this problem ceased to be considered. The problem resulted in serious dissatisfaction in the residents.

The results in Table 7 reveal that the Kaiping government made outstanding achievements in the community environment, such as decreases in solid waste and silt. Residents' attention toward environmental protection could be improved by the exposure effect of tourism and education of the government. Although tourism increased the environmental destruction, residents usually did not consider it an issue.

\subsection{Political dimension}

(1) Community participation

Existing studies usually focused more on community participation in tourism (Andereck \& Vogt, 2000), but community participation in the decision making of WHSs was also important. The WHL inscription required community participation heritage management, protection and development, among others (ICOMOS International Committee on Cultural Tourism, 1999). Respondents (five in Sanmenli, seven in Zili, six in Jinjiangli and seven in Majianglong) stated that they were encouraged to engage in village renovation, such as repairing walls, paving roads, cleaning villages and other related affairs, prior to WHL inscription. They were willing to devote their efforts to the WHL inscription. In addition, the government negotiated several times with residents on the issue of Diaolou property rights and management. These behaviours made the residents feel that community participation was improved by the WHL inscription and that their ideas were considered and respected by the government.

\section{(2) Government leadership}

In Chinese cities, top-down political governance exists, which determines the leadership of the government in regional development (Zhang, Sun, \& Huang, 2018). How- ever, the hierarchical leadership embodied in the WHL inscription was less studied. Respondents showed that the inscription of Kaiping Diaolou and Villages was effectively handled by the Kaiping government. To inscribe Kaiping Diaolou and Villages on the WHL, the Kaiping municipal government formed special working group Leading Group of World Cultural Heritage Designation in 2000. This leading group consisted of rectification, information and branding group offices. All the detailed affairs related to the WHL inscription belonged to this leading group. Kaiping is a county-level city that is supervised by the prefecture-level city Jiangmen. Accordingly, the Leading Group of World Cultural Heritage Designation in Jiangmen was constructed to improve the census of Diaolou buildings in 2001. After receiving the recognition of Diaolou's value from ICOMOS experts, a provincial-level working group was formed in 2001 by the Guangdong provincial government to effectively promote the WHL inscription. A completely hierarchical governance of the WHL inscription of the heritage had been formed since then. Most respondents felt that a hierarchical governance structure was useful for the WHL inscription in China.

Respondents also reported that during the WHL inscription, different associations, experts and stakeholders engaged in the process under the leadership of the government. The plan of the WHL inscription was first put forward at the meeting of the overseas Chinese delegation in Hong Kong. Given the close relation of Diaolou with overseas Chinese, the WHS designation was greatly supported by the overseas Chinese delegation. Experts from different organisations (e.g. ICOMOS, Peking University, Tsinghua University and Wuyi University) engaged in the analysis of OUVs, census of Diaolou, creation of the nominee text and Protection and Management Planning. Stakeholders mainly included the local residents, owners of Diaolou and the tourism company. All the respondents felt that the success of the WHL inscription was mostly due to the correct leadership of the government and its effective cooperation with different organisations and stakeholders.

(3) Plan and legislation

The Protection and Management Plan was required to be submitted with WHL inscription text during the nomination process and revised after the WHL inscription 
(ICOMOS International Committee on Cultural Tourism, 1999). Dominated by the local government of Kaiping, experts in the World Heritage Centre of Peking University and ICOMOS were invited to compile the Protection and Management Plan of Kaiping Diaolou in 2005. In 2011, this plan was revised by experts of Peking University and Wuyi University to meet the latest requirements of the World Heritage Committee. Villagers were deeply impressed by the field investigations for these planning sessions. Therefore, the investigation works of these experts left deep impressions on most respondents. Respondents (five in Sanmenli, six in Zili, five in Jinjiangli and seven in Majianglong) felt that the protection and management planning was beneficial for the WHL inscription.

Before the WHL inscription, the government of Kaiping published the Regulation on the Protection and Management of Kaiping Diaolou and Villages, and the government of Guangdong Province published the Interim Provisions on the Protection and Management of Diaolou in Kaiping to protect and manage the heritage effectively. After the WHL inscription, these regulations were reasonably revised. In 2008, the Kaiping government implemented the Interim Measures for the Protection and Management of World Heritage Sites 'Kaiping Diaolou and Village'. Respondents (four in Sanmenli, six in Zili, six in Jinjiangli and five in Majianglong) felt that these regulations effectively protected the WHS, and people adopted environmentally friendly behaviours.

(4) Limited participation

Although residents participated in the heritage protection and management, most of them showed limited participation in the decision-making and heritage development after the WHL inscription. The heritage sites were managed by the tourism company, which was built up and directly supervised by the government of Kaiping. Therefore, the community committee had minimal influence. The hierarchical governance system gave few opportunities for the residents to participate in decision-making and heritage development. Given their low average level of education, most of the residents were not hired as administrative staff in the tourism company. The absence of a local representa- tive in the main body of the governance, especially when confronted with conflicts of interest, was unfair for residents.

(5) Insufficient planning

Respondents (seven in Sanmenli, five in Zili, six in Jinjiangli and four in Majianglong) revealed that the government did not plan any tourism project for the WHSs. They eagerly hoped that some tourism projects could be funded by the government to help them participate in heritage development. This condition reflected that a tourism development plan was needed for Kaiping Diaolou WHS. Tourists greatly increased after the WHL inscription, and tourism played an important role in the economic development of Kaiping. The villages of Zili, Jinjiangli and Majianglong were a component of the 'National 4A Famous Scenic' of Kaiping Diaolou'. However, the government still had not accomplished a tourism development plan. No reasonable travel tour was available to connect the core areas together. Tourism programs and facilities were also lacking.

The political impacts of the WHL inscription can be arranged into four sub-dimensions, as shown in Table 8. Community participation was improved for the WHL inscription, and several organisations and stakeholders were engaged in it. However, the governance system remained hierarchical. Thus, works of heritage planning, protection, management, development and others were controlled by the government. The government was at the top of this hierarchical structure, which may have led to the irrational plan and limited participation of the community.

\section{Discussion and implications}

\subsection{Discussion}

To investigate the impacts of WHL inscription, Kaiping Diaolou and Villages was chosen as a case study. A series of in-depth interviews was conducted to analyse the impacts of the WHL inscription. We found that the impacts of the WHL inscription could be categorised into four aspects: social and cultural, economic, environmental and

Table 8. Impacts of the WHL inscription from the political aspect (source: field survey)

\begin{tabular}{|c|c|c|c|c|c|c|}
\hline & Sub-dimensions & Meaning unit & Sanmenli & Zili & Jinjiangli & Majiang-long \\
\hline \multirow[t]{5}{*}{ Benefits } & $\begin{array}{l}\text { Community } \\
\text { participation }\end{array}$ & $\begin{array}{l}\text { Participating in heritage protection and } \\
\text { management }\end{array}$ & 5 & 7 & 6 & 7 \\
\hline & \multirow[t]{2}{*}{$\begin{array}{l}\text { Government } \\
\text { leadership }\end{array}$} & $\begin{array}{l}\text { Forming special working groups for the } \\
\text { WHL inscription }\end{array}$ & 8 & 8 & 8 & 8 \\
\hline & & $\begin{array}{l}\text { Engagement of different stakeholders and } \\
\text { organisations }\end{array}$ & 8 & 8 & 8 & 8 \\
\hline & \multirow[t]{2}{*}{ Plan and legislations } & Protection and Management Plan & 5 & 6 & 5 & 7 \\
\hline & & Management legislation & 4 & 6 & 6 & 5 \\
\hline \multirow[t]{2}{*}{ Costs } & Limited participation & $\begin{array}{l}\text { Limited participating in decision-making } \\
\text { and heritage development }\end{array}$ & 6 & 5 & 5 & 4 \\
\hline & Insufficient planning & Being lack of tourism development plan & 7 & 5 & 6 & 4 \\
\hline
\end{tabular}


political. Based on the findings of this study, the influencing model of WHL inscription in Kaiping Diaolou and Villages was formed, as shown in Figure 10.

In the social and cultural domain, the positive impacts of the WHL inscription were the central themes, and they were more obvious than the negative impacts. The social and cultural benefits mainly included the promotion of local cultural cognition, promotion of the sense of belonging, enhancement of community cohesion and improvement of infrastructure. Given the nature of the world cultural heritage designation, the local cultural cognition was obviously and directly improved by acquiring knowledge about history, culture and heritage. The WHL inscription enhanced the sense of belonging and community cohesion, but the willingness of residents to live and work at home was still decided by employment opportunities. Thus, survival remained the most basic task for Chinese rural people. The negative impact on the social community environment was not serious because the incidents of theft increased alongside the growth of tourism.
In the economic domain, the WHL inscription had positive and negative impacts. The positive impacts included the increase in tourism development, increase in villagers' income and employment and the solution to some heritage property rights problems. The negative impacts were worse tourism development than previous expectations, inequality of income and employment and unsolved heritage property rights problems. Tourism development was important for the local community because it diversified employment and income. With the title of WHS, the residents easily had higher expectations for the tourism benefits than they did before. Thus, the disappointment with the actual outcome was possible. However, the residents still opted for the improvement of tourism development instead of reducing their support. In a WHS, where a community of local residents was also present, properly solving the heritage property rights problems was critical for WHS management. The trusteeship system adopted in Kaiping Diaolou and Villages was first applied to the management of heritage in China. It was beneficial for the

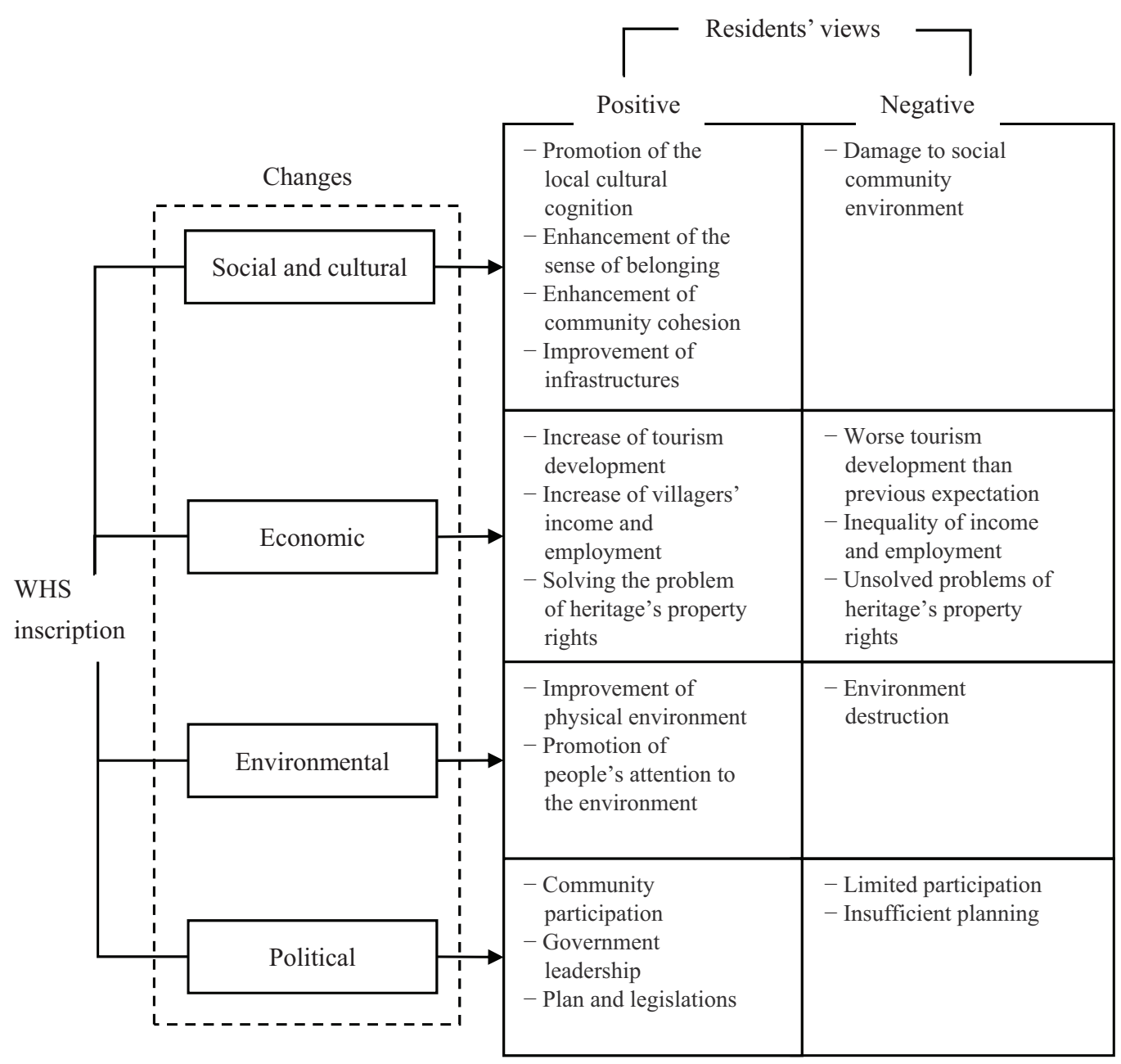

Figure 10. Present factors of the WHL inscription's impacts on community of Kaiping Diaolou and Villages (source: field survey) 
government and the residents and could shed light on the other WHSs in China.

In the environmental domain, the WHL inscription improved the environment and people's attention to environmental protection, but it also caused some environmental destruction due to the increasing number of tourists. To receive the WHL inscription, the government greatly improved the environment (mainly cleaning rivers, ponds, solid waste, roads and walls). Residents' awareness of environmental protection can be improved by the exposure effect of tourism and education of the government. However, residents still did not consider environmental destruction an important issue. This fact reflected that, in comparison with the environment, residents still prioritised economic benefits.

In the political domain, the positive impacts of the WHL inscription comprised government leadership, community participation and plans and legislation, whereas the negative impacts included limited community participation and insufficient planning of the WHS. The situation of government leadership reflected the hierarchical governance structure of the WHL inscription. The entire process of WHL inscription was controlled by a top-down system. This system was reasonable because it ensured the effectiveness of the WHL inscription process. The government dominated the plans and legislation of the WHS, which were considered beneficial for the WHL inscription and WHS protection by most residents. Community participation and engagement of organisations and stakeholders were also improved in the WHL inscription. However, this top-down governance system also led to problems, such as limited participation of the community and insufficient planning for the WHS. Thus, the government must grant additional speaking rights to local residents.

\subsection{Contribution}

This study theoretically contributes to the field of world heritage management, and it involves constructing a theoretical framework and modelling the social and cultural, economic, environmental and political impacts of WHL inscription from residents' perspective. Previous studies on the impact of WHL inscription usually focus on a particular aspect, such as tourism activities, sense of pride and environmental protection (Caust \& Vecco, 2017; Jimura, 2011; Jones et al., 2017; Melanie, 2002; Parga Dans \& Alonso González, 2019; Wang \& Bramwell, 2012). The current study systematically analysed the impacts of the social and cultural, economic, environmental and political dimensions. The theoretical framework can be applied in the following studies to estimate the impact of other examples WHL inscription. In addition, the detailed results of Kaiping Diaolou and Villages are provided for comparison with other WHSs.

\subsection{Development implications}

Estimating the impacts of the WHL inscription from residents' perspective has several implications for the sustainable development of WHSs and the property management.
Firstly, in the social and cultural domain, animating the local culture is important. Simply introducing the history and the culture of the WHS via archives is tedious. By exploring the factors related to the culture of WHSs, culture industries, such as film and photography, can be developed. They can also be related to tourism development. Cultural studios and workshops can be opened in the WHSs, which can attract visitors and animate local culture. However, the authenticity of culture should be well maintained which have to be noticed during development process controlling by the real estate company.

Secondly, in the economic domain, income and employment must be improved and diversified for the local communities. Tourism is a suitable industry for WHSs. Local government should give preferential policies to support local residents in the tourism business. The different core areas have development gaps. Hence, corresponding tourism strategies should be made. Less-developed villages can be given additional attention or be prioritised in attempts to develop new industries, such as cultural industries. However, the government and the real estate company should attempt to maintain a balance between protection and development. Excessive tourism should neither damage the values of the WHS nor become a synonym for poverty.

Thirdly, in the environmental domain, the environment of WHSs should be protected, and residents' awareness of it should be improved. The environment is critical for the integrity and authenticity of WHSs, but which also be neglected by the development group. Protection is also the most important purpose of WHL inscription as climate change and environmental protection are existing global issues. Damage to the environment is mainly related to excessive tourism development. Balancing tourism and environment is an important issue for the sustainable development of WHSs.

Finally, in the political domain, community participation in decision-making should be improved. Improving community participation in the management and development of WHSs is required by the UNESCO World Heritage Committee. Although top-down governance is reasonable and effective in China, the requirements of the residents in WHSs cannot be ignored, especially when the WHS is also a residential community.

\section{Acknowledgements}

The authors are grateful for the financial support from, the Agricultural Science and Technology Innovation Program (ASTIP-IAED-2019-04), the National Natural Science Foundation of China (No. 71734001), the National Natural Science Foundation of China (No. 71904009), MOE (Ministry of Education in China) Project of Humanities and Social Sciences (No. 18YJC840041) and State Ethnic Affairs Commission of China Project (No. 2018-GMB-041). The authors gratefully the anonymous reviewers for insightful comments that helped us improve the quality of the paper. 


\section{Author contributions}

$\mathrm{WH}$ and YW conceived the study and were responsible for the design and development of the data analysis. JC and $\mathrm{YZ}$ were responsible for conceptual design. $\mathrm{WH}$ and $\mathrm{YH}$ were responsible for data analysis.

\section{Disclosure statement}

The authors declare no conflict of interest in this paper.

\section{References}

Adie, B. A. (2017). Franchising our heritage: the UNESCO World Heritage brand. Tourism Management Perspectives, 24, 48-53. https://doi.org/10.1016/j.tmp.2017.07.002

Airey, D., \& Shackley, M. (1998). Chapter 2 - Bukhara (Uzbekistan): a former oasis town on the Silk Road. In Visitor Management (pp. 10-25). Oxford: Butterworth-Heinemann. https://doi.org/10.1016/B978-0-7506-4783-0.50005-7

Andereck, K. L., \& Vogt, C. A. (2000). The relationship between residents' attitudes toward tourism and tourism development options. Journal of Travel Research, 39(1), 27-36. https://doi.org/10.1177/004728750003900104

Andriotis, K., \& Vaughan, R. D. (2003). Urban residents' attitudes toward tourism development: the case of Crete. Journal of Travel Research, 42(2), 172-185.

https://doi.org/10.1177/0047287503257488

Bengtsson, M. (2016). How to plan and perform a qualitative study using content analysis. Nursingplus Open, 2(2), 8-14. https://doi.org/10.1016/j.npls.2016.01.001

Bianchi, R. V. (2002). The contested landscapes of world heritage on a tourist island: the case of Garajonay National Park, La Gomera. International Journal of Heritage Studies, 8(2), 81-97. https://doi.org/10.1080/13527250220143896

Braun, V., \& Clarke, V. (2006). Using thematic analysis in psychology. Qualitative Research in Psychology, 3(2), 77-101. https://doi.org/10.1191/1478088706qp063oa

Bremner, L. (2000). Reinventing the Johannesburg inner city. Cities, 17(3), 185-193.

https://doi.org/10.1016/S0264-2751(00)00013-5

Burnard, P. (1991). A method of analysing interview transcripts in qualitative research. Nurse Education Today, 11(6), 461466. https://doi.org/10.1016/0260-6917(91)90009-Y

Caust, J., \& Vecco, M. (2017). Is UNESCO World Heritage recognition a blessing or burden? Evidence from developing Asian countries. Journal of Cultural Heritage, 27, 1-9. https://doi.org/10.1016/j.culher.2017.02.004

Chen, Y., Chen, Z., Xu, G., \& Tian, Z. (2016). Built-up land efficiency in urban China: insights from the General Land Use Plan (2006-2020). Habitat International, 51, 31-38. https://doi.org/10.1016/j.habitatint.2015.10.014

Cheng, Y., \& Zhang, J. (2013). Features and protection-utilization of Kaiping Diaolou and Villages on the basis of comparative analysis. Ecological Economy, 1, 184-187.

Cuccia, T., Guccio, C., \& Rizzo, I. (2016). The effects of UNESCO World Heritage List inscription on tourism destinations performance in Italian regions. Economic Modelling, 53, 494-508. https://doi.org/10.1016/j.econmod.2015.10.049

Evans, G. (2002). Living in a World Heritage City: stakeholders in the dialectic of the universal and particular. International Journal of Heritage Studies, 8(2), 117-135. https://doi.org/10.1080/13527250220143913
Frey, B. S. (2013). Explaining the World Heritage List: an empirical study. International Review of Economics, 60(1), 1-19. https://doi.org/10.1007/s12232-013-0174-4

Gordon, I., \& Brian, G. (2000). Localities and tourism. Tourism Geographies, 2(3), 290-311. https://doi.org/10.1080/14616680050082535

Griffin, T. (2013). Research note: a content analysis of articles on visiting friends and relatives tourism, 1990-2010. Journal of Hospitality Marketing \& Management, 22(7), 781-802. https://doi.org/10.1080/19368623.2012.708960

Han, W., Zhang, Y., Cai, J., \& Ma, E. (2019). Does urban industrial agglomeration lead to the improvement of land use efficiency in China? An empirical study from a spatial perspective. Sustainability, 11(4), 986. https://doi.org/10.3390/su11040986

Hewison, R. (1987). The heritage industry: Britain in a climate of decline. London: Methuen London.

ICOMOS International Committee on Cultural Tourism. (1999). Tourism at world heritage sites: the site manager's handbook. Madrid: WTO.

Jha, S. (2005). Can Natural World Heritage Sites promote development and social harmony? Biodiversity \& Conservation, 14(4), 981-991. https://doi.org/10.1007/s10531-004-7837-0

Jimura, T. (2011). The impact of world heritage site designation on local communities - a case study of Ogimachi, Shirakawamura, Japan. Tourism Management, 32(2), 288-296.

https://doi.org/10.1016/j.tourman.2010.02.005

Jones, T. E., Yang, Y., \& Yamamoto, K. (2017). Assessing the recreational value of world heritage site inscription: a longitudinal travel cost analysis of Mount Fuji climbers. Tourism Management, 60, 67-78.

https://doi.org/10.1016/j.tourman.2016.11.009

Kim, S. S., Wong, K. K. F., \& Cho, M. (2007). Assessing the economic value of a world heritage site and willingness-to-pay determinants: a case of Changdeok Palace. Tourism Management, 28(1), 317-322. https://doi.org/10.1016/j.tourman.2005.12.024

Kolar, T., \& Zabkar, V. (2010). A consumer-based model of authenticity: an oxymoron or the foundation of cultural heritage marketing? Tourism Management, 31(5), 652-664. https://doi.org/10.1016/j.tourman.2009.07.010

Kovács, Z., Wiessner, R., \& Zischner, R. (2013). Urban renewal in the inner City of Budapest: gentrification from a post-socialist perspective. Urban Studies, 50(1), 22-38. https://doi.org/10.1177/0042098012453856

Krippendorff, K. (2004). Content analysis: an introduction to its methodology. Thousand Oaks, California: Sage Publications Inc.

Leask, A., \& Fyall, A. (2006). Managing world heritage sites. Oxford: Butterworth-Heinemann. https://doi.org/10.4324/9780080461755

Li, F., Wang, G., Li, Y., \& Zhou, R. (2017). Job demands and driving anger: the roles of emotional exhaustion and work engagement. Accident Analysis \& Prevention, 98, 198-205. https://doi.org/10.1016/j.aap.2016.10.013

Luo, N., Zhang, M., Hu, M., \& Wang, Y. (2016). How community interactions contribute to harmonious community relationships and customers' identification in online brand community. International Journal of Information Management, 36(5), 673-685. https://doi.org/10.1016/j.ijinfomgt.2016.04.016

Ma, S. C., Fan, Y., \& Feng, L. (2017). An evaluation of government incentives for new energy vehicles in China focusing on vehicle purchasing restrictions. Energy Policy, 110, 609-618. https://doi.org/10.1016/j.enpol.2017.07.057 
Melanie, S. (2002). A critical evaluation of the global accolade: the significance of World Heritage Site status for Maritime Greenwich. International Journal of Heritage Studies, 8(2), 137-151. https://doi.org/10.1080/13527250220143922

Mihalik, B. J., \& Simoneita, L. (1998). Resident perceptions of the 1996 Summer Olympic Games-Year II. Festival Management \& Event Tourism, 5(1-2), 9-19.

https://doi.org/10.3727/106527098792186676

Naudé, W. A., \& Saayman, A. (2005). Determinants of tourist arrivals in Africa: a panel data regression analysis. Mpra Paper, 11(3), 365-391.

https://doi.org/10.5367/000000005774352962

Newby, P. (1990). Tourist development. Applied Geography, 10(4), 357-358. https://doi.org/10.1016/0143-6228(90)90041-M

Nicholas, L., \& Thapa, B. (2010). Visitor perspectives on sustainable tourism development in the Pitons Management Area World Heritage Site, St. Lucia. Environment Development \& Sustainability, 12(5), 839-857.

https://doi.org/10.1007/s10668-009-9227-y

Noor, S., Rasoolimanesh, S. M., Jaafar, M., \& Barghi, R. (2018). Inscription of a destination as a World Heritage Site and residents' perceptions. Asia Pacific Journal of Tourism Research, 1-40.

Parga Dans, E., \& Alonso González, P. (2019). Sustainable tourism and social value at World Heritage Sites: towards a conservation plan for Altamira, Spain. Annals of Tourism Research, 74, 68-80. https://doi.org/10.1016/j.annals.2018.10.011

Poria, Y., Reichel, A., \& Cohen, R. (2013). Tourists perceptions of World Heritage Site and its designation. Tourism Management, 35(2), 272-274.

https://doi.org/10.1016/j.tourman.2012.02.011

Rasoolimanesh, S. M., Roldán, J., Jaafar, M., \& Ramayah, T. (2017). Factors influencing residents' perceptions toward tourism development: differences across rural and urban World Heritage Sites. Journal of Travel Research, 56(6), 760775. https://doi.org/10.1177/0047287516662354

Santa-Cruz, F. G., \& López-Guzmán, T. (2017). Culture, tourism and World Heritage Sites. Tourism Management Perspectives, 24, 111-116.

Shackley, M. (Ed.). (1998). Chapter 12 - Conclusions - visitor management at cultural World Heritage Sites. In Visitor management (pp. 194-205). Oxford: Butterworth-Heinemann. https://doi.org/10.1016/B978-0-7506-4783-0.50015-X

$\mathrm{Su}, \mathrm{X}$. (2015). Urban entrepreneurialism and the commodification of heritage in China. Urban Studies, 52(15), 2874-2889. https://doi.org/10.1177/0042098014528998

Su, Y. W., \& Lin, H. L. (2014). Analysis of international tourist arrivals in China: the role of World Heritage Sites. Tourism Management, 40(6), 46-58.

https://doi.org/10.1016/j.tourman.2013.04.005

Timothy, D. J. (2011). Cultural heritage and tourism: an introduction. Cultural Heritage \& Tourism an Introduction, 2(1), 123-126.

UNESCO World Heritage Centre. (2017). Operational Guidelines for the Implementation of the World Heritage Convention (Vol. WHC/17/41.COM/11, 2017). Retrieved from http://whc. unesco.org/en/guidelines (English).

Urban Planning and Design Center of Peking University. (2006). Protection and Management Plan on Kaiping Diaolou and Villages (extracts). Retrieved from http://whc.unesco.org/en/ documents/104657

Wager, J. (1995). Developing a strategy for the Angkor World Heritage Site. Tourism Management, 16(7), 515-523.

https://doi.org/10.1016/0261-5177(95)00069-Z
Wang, C. H., Lin, L. U., \& Xia, Q. Y. (2012). Research progress and enlightenment on tourism impacts of mega event. Journal of Natural Resources, 27(6), 1053-1067.

Wang, Y., \& Bramwell, B. (2012). Heritage protection and tourism development priorities in Hangzhou, China: a political economy and governance perspective. Tourism Management, 33(4), 988-998. https://doi.org/10.1016/j.tourman.2011.10.010

Wang, Z., Yang, Z., Wall, G., Xu, X., Fang, H., Du, X., \& Liu, Q. (2015). Is it better for a tourist destination to be a World Heritage Site? Visitors' perspectives on the inscription of Kanas on the World Heritage List in China. Journal for Nature Conservation, 23, 19-26. https://doi.org/10.1016/j.jnc.2014.11.001

Wann-Hansson, C., Hallberg, I. R., Klevsgård, R., \& Andersson, E. (2005). Patients' experiences of living with peripheral arterial disease awaiting intervention: a qualitative study. International Journal of Nursing Studies, 42(8), 851-862.

https://doi.org/10.1016/j.ijnurstu.2004.11.009

Wei, Y., Cui, H., Lam, P. T. I., \& Yuan, Z. (2015). Sustainable urban development: a review on urban carrying capacity assessment. Habitat International, 46, 64-71. https://doi.org/10.1016/j.habitatint.2014.10.015

Wei, Y., Gu, J., Wang, H., Yao, T., \& Wu, Z. (2018). Uncovering the culprits of air pollution: evidence from China's Economic sectors and regional heterogeneities. Journal of Cleaner Production, 171, 1481-1493. https://doi.org/10.1016/j.jclepro.2017.09.246

Wei, Y., Huang, C., Lam, P. T. I., Sha, Y., \& Feng, Y. (2015). Using urban-carrying capacity as a benchmark for sustainable urban development: an empirical study of Beijing. Sustainability, 7(3), 3244-3268. https://doi.org/10.3390/su7033244

Wei, Y., Huang, C., Li, J., \& Xie, L. (2016). An evaluation model for urban carrying capacity: a case study of China's megacities. Habitat International, 53, 87-96. https://doi.org/10.1016/j.habitatint.2015.10.025

Wei, Y., Lam, P. T. I., Chiang, Y. H., \& Leung, B. Y. P. (2014). The effects of monetary policy on real estate investment in China: a regional perspective. International Journal of Strategic Property Management, 18(4), 368-379.

https://doi.org/10.3846/1648715X.2014.971087

Wei, Y., Wang, Z., Wang, H., Yao, T., \& Li, Y. (2018). Promoting inclusive water governance and forecasting the structure of water consumption based on compositional data: a case study of Beijing. Science of the Total Environment, 634, 407416. https://doi.org/10.1016/j.scitotenv.2018.03.325

While, A. (2006). Modernism vs urban renaissance: negotiating post-war heritage in English city centres. Urban Studies, 43(13), 2399-2419. https://doi.org/10.1080/00420980601038206

Wilson, C. (2013). Interview techniques for UX practitioners. Interview Techniques for Ux Practitioners, 119-122. https://doi.org/10.1016/B978-0-12-410393-1.00004-1

Wu, M., Wei, Y., Lam, P. T. I., Liu, F., \& Li, Y. (2019). Is urban development ecologically sustainable? Ecological footprint analysis and prediction based on a modified artificial neural network model: a case study of Tianjin in China. Journal of Cleaner Production, 237, 1-15. https://doi.org/10.1016/j.jclepro.2019.117795

Yang, C.-H., Lin, H.-L., \& Han, C.-C. (2010). Analysis of international tourist arrivals in China: the role of World Heritage Sites. Tourism Management, 31(6), 827-837. https://doi.org/10.1016/j.tourman.2009.08.008

Yao, T., Qiu, Q., \& Wei, Y. (2019). Retaining hotel employees as internal customers: effect of organizational commitment on attitudinal and behavioral loyalty of employees. International Journal of Hospitality Management, 76(Part A), 1-8. https://doi.org/10.1016/j.ijhm.2018.03.018 
Yu, X. (2014). Is environment 'a city thing' in China? Rural-urban differences in environmental attitudes. Journal of Environmental Psychology, 38, 39-48.

https://doi.org/10.1016/j.jenvp.2013.12.009

Zhang, M., Guo, L., Mu, H., \& Liu, W. (2017). Influence of customer engagement with company social networks on stickiness: mediating effect of customer value creation. International Journal of Information Management, 37(3), 229-240. https://doi.org/10.1016/j.ijinfomgt.2016.04.010

Zhang, Q., Sun, Z., \& Huang, W. (2018). Does land perform well for corn planting? An empirical study on land use efficiency in China. Land Use Policy, 74, 273-280.

https://doi.org/10.1016/j.landusepol.2017.10.032
Zhu, L., Peng, P., Wang, X., \& Fan, Y. (2018). Exploring optimal mitigation and adaptation investment strategies in China. Climate Policy, 18(6), 781-793.

https://doi.org/10.1080/14693062.2017.1382320

Zhu, X., Li, Y., Zhang, P., Wei, Y., Zheng, X., \& Xie, L. L. (2019). Temporal-spatial characteristics of urban land use efficiency of China's 35 mega cites based on DEA: decomposing technology and scale efficiency. Land Use Policy, 88, 1-13. https://doi.org/10.1016/j.landusepol.2019.104083 